\title{
Factors enhancing innovation in IT outsourcing Firms: A case from Karachi - Pakistan
}

\author{
Muhammad Nadeem Jahangir ${ }^{1}$, Qazi Muhammad Moinuddin Abro ${ }^{1}$, \\ *Muhammad Nawaz Tunio ${ }^{1}$, Imdad Ali Bughio ${ }^{1}$ \\ ${ }^{\prime}$ (Mehran University of Engineering and Technology, Jamshoro, Pakistan) \\ mntunio@gmail.com
}

\begin{abstract}
Recent studies have revealed that the present uplift in information technology (IT) business in Pakistan is due to rising trend of Business Process Outsourcing and IT outsourcing services to domestic as well as global firms. Pakistan's IT industry is constantly growing and outsourcing business is putting positive impact on its growth. This study seeks to investigate the most influential factors that may have contributions toward enhancing/facilitating performance and innovation in ITO firms working in the city of Karachi which is considered as the business hub of Pakistan.
\end{abstract}

Keywords: Information Technology, Information Technology Enabled Services, Foreign Direct Investment, Research and Development, Business Process Outsourcing.

\section{Introduction}

The use of information technology (IT) has tremendously increased in Pakistan, especially in last ten years it has become an integral part of every business strategy (PASHA, 2007). Different sectors like Engineering, Health, Banking, Pharmaceutical etc are making use of IT as mandatory part of their functions. In 90's Pakistan was nowhere in the software developing countries, even it had lenient basic infrastructure. In order to facilitate information technology activities in the country, Government of Pakistan took some noteworthy initiatives which included tax exemption for IT firms/companies till 2016, $100 \%$ ownership of equity, investment was allowed in overseas IT/ITeS companies, providing land for IT parks with low rent, funds provided for software companies to achieve ISO-9000 certifications (CMM/CMMI rating) and 100\% returns of profits allowed to IT companies (MoIP, 2004; PSEB, 2007-08). These initiatives played a significant role in strengthening software industry, especially IT education in schools, colleges and universities, produced abundance of specialized IT Human Resource (MoIP, 2004).

During 2000 to 2004, Government of Pakistan approved 200 new projects for facilitating use of IT and Telecom in other different sectors (like Education and Health) and adopted pro-active approach towards encouraging Business Process Outsourcing (BPO) for the first time in order to attract Foreign Direct Investment (FDI) in the country (MoIP, 2004). Though it was a bit late for Pakistan, going towards outsourcing business unlike its neighboring countries but later it became a real boost for its IT industry.

As a result, outsourcing industry of Pakistan started showing its impact over global market. Gartner's report (as cited by PASHA, 2007) declared Pakistan as most suitable offshore outsourcing destination due to its lowest labour cost in any outsourcing destination and World Bank report put Pakistan at No. 2 due to ease of doing business in South Asia (PASHA, 2007). Even in-spite of social, political, economical instability and constantly rising software piracy, Pakistan IT industry reported as 2 billions USD industry in 2007 (PASHA, 2007; BSA, 2007). The same has been acknowledged by the famous Management Consultancy Company AT Kearney, which ranked Pakistan the $20^{\text {th }}$ most gorgeous nation in its 2009 Global Services position directory (Ahmed et al. 2012).

In another place Ahmed et al. (2012) highlighted that Pakistan's IT industry is growing and outsourcing is putting positive impact on its growth. As the Global IT outsourcing trend is increasing, the same has been observed in IT industry of Pakistan. By outsourcing, the domestic and global business firms borrow IT services from other specialized firms (supplier) in order to excel their core services and expect innovative solutions in return in non-core services. The concept of attaining innovation through outsourcing has extensively studied and considered as a valuable approach towards innovation (Marion and Friar, 2012). The same has pushed this study to investigate whether the significance of outsourcing putting positive impact on innovative capabilities of an Information Technology Outsourcing (ITO) firm which is causing such uplift in IT industry or it's just a myth that outsourcing IT services enhances innovation. 


\section{Innovative Capabilities of A Business Firm}

The 'innovative capabilities' of a business firm is considered as the ability to produce new products, services and to discover new markets by utilizing strategic skills to reach a novel outcome (Talaja, 2012; Wang and Ahmed, 2007). In a client-supplier relationship, this can be done when a firm acquires new and unfamiliar IT capabilities for reinventing business practices or processes (Whitman, 1996). This has been further elaborated by Hoecht and Trott that the innovation in IT outsourcing firm is considered as to gain access of new technology, skills, competencies and expertise which a firm cannot develop in-house (Hoecht and Trott, 2006). Such aspects have been kept under consideration during this study in order to find out the possible impact of IT outsourcing over innovative capabilities. As initiatives need policies and practices of e-services to understand and meet the citizen demands (Tunio, et. al., 2013). Better provisions of interactional and transactional facilities need effective strategy and implementation of e-services to benefit the business at national and international level (Mahar, et. al., 2013).

\section{Influential Factors In It Outsourcing}

In outsourcing literature, the client-supplier contractual relationship or legal binding plays significant role in excelling mutual learning capabilities and innovativeness of the outcome through knowledge transfer. In fact such contractual relationship sets the modalities for implementing collaborative efforts for innovation. Such partnership increases creativity in R\&D and facilitates skills transmission in the firm. According to Oslo Manual (2005) R\&D and innovation is considered as the closely related phenomena for measuring capacity building and utilizing new knowledge at the firm-level (micro-level) but some Small Medium Enterprises (SMEs) outsource some of their R\&D tasks to other professional firms to cut down R\&D costs $(\mathrm{Li}, 2011)$. There are some other factors like ease of communication, skills transmission, accumulation of knowledge within and between firms, effective channels of information and IPRs are also noteworthy. Such factors play significant role in case when positive attitude is been shown by both the external and internal linkages of firm for the adoption of new or improved methods or technology (Oslo Manual, 2005).

In another place Stanko and Calantone (2011) emphasized over the need of legal protection for innovation which is produced by firms, in form of intellectual property rights to secure innovation from imitation by other competitors.

Factors That May Affect/Facilitate Innovation In A Client-Supplier Relationship

\begin{tabular}{|c|c|c|}
\hline SR. & FACTORS & SOURCE \\
\hline 1. & Positive Attitude to innovate. & Oslo Manual, 2005 \\
\hline 2. & Research \& Development & Li 2011, Oslo Manual, 2005 \\
\hline 3. & Skills Transmission & Oslo Manual 2005 \\
\hline 4. & Accumulation of knowledge within firm and between firms & Oslo Manual 2005 \\
\hline 5. & Effective Channels of Information & Oslo Manual 2005 \\
\hline 6. & IPR \& Regulations & $\begin{array}{l}\text { Stanko \& Calantone 2011, } \\
\text { Oslo Manual } 2005\end{array}$ \\
\hline 7. & Contractual Relationship & Oshri \& Kotlarsky, 2011 \\
\hline
\end{tabular}

Table 3.1: List of factors that may affect/facilitate innovation in a client-supplier relationship in any IT outsourcing firm or company. 


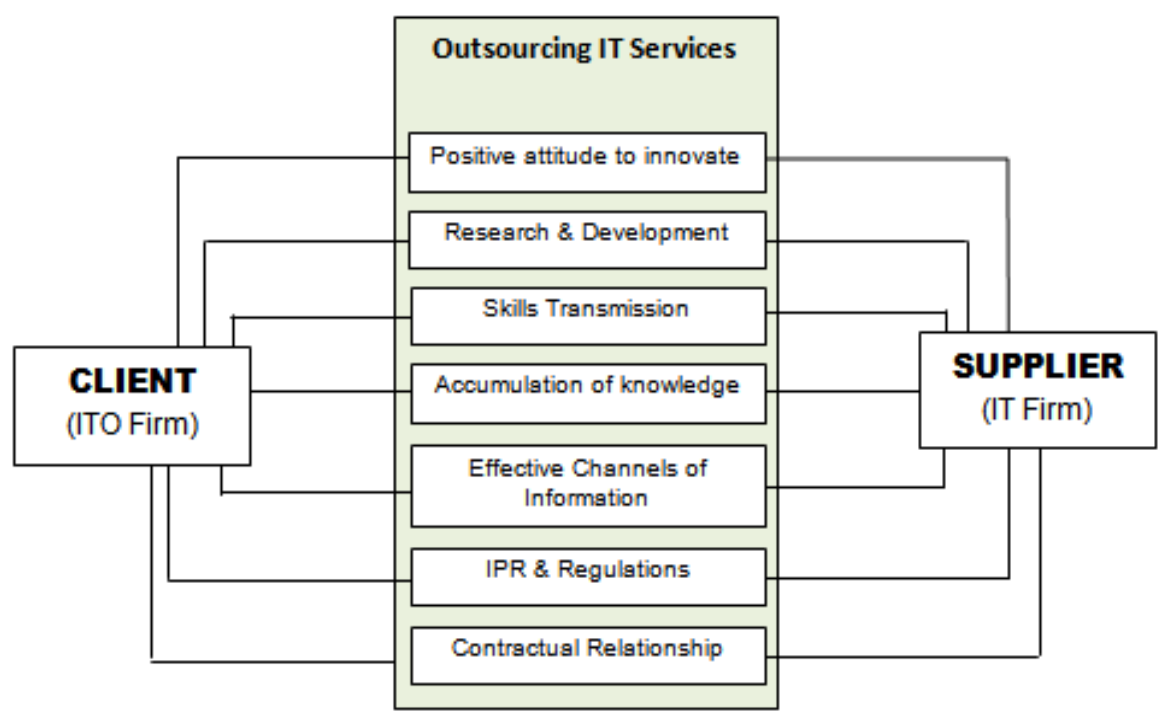

Fig. 3.1: Factors in a client-supplier relationship model.

\section{Research Objectives}

Main purpose of this study is to identify the most influential factors that may have contribution towards enhancing/facilitating performance and innovative capabilities of ITO firm of Karachi in light of the concept that outsourcing IT services facilitates innovation in an organization (Marion and Friar, 2012). In this study, ITO firms of Karachi are mainly focused due to easy access of data and a large pool of active IT firms working in the region.

\section{Research Methodology}

Selecting methodology is an important step for conducting any research. In this study, both the qualitative and quantitative methodologies have been applied. Strauss and Corbin (1990) defined qualitative research (as cited by Golafshani, 2003) that "any kind of research that produces findings not arrived at by means of statistical procedures or other means of quantification" whereas, quantitative research is the mode of empirical study based on statistical experimentation and analysis (Golafshani, 2003). In this study observations are measured quantitatively in light of comments, discussions and remarks recorded during surveys and interviews. The preliminary information regarding factors have been collected through an extensive literature review of relevant research articles, survey reports and case studies of the successful companies borrowing IT services or IT related technologies from specialized firms.

\subsection{Sample Selection}

Business firms of Karachi, who are outsourcing IT services have been selected for conducting this study because of large number of active IT firms working in the city and easy access of data. About 170 business firms sampled out of 300 firms have been randomly selected.

\subsection{Data Collection}

Heads/CEOs and managerial level officers of firms were been interviewed during the survey and questionnaires were served to all respondents via various sources of communications i.e. e-mails, telephonic interviews, scheduled meetings and personal visit. During visits, firm level managers or representatives of the IT firms (Suppliers) were also been interviewed for better understanding of outsourcing related issues in connection to innovation. In the end the collected data is analyzed through SPSS (Statistical Package for Social Sciences) software which is an important statistical tool for interpreting the collected statistics in order to reach comprehensive conclusions. 


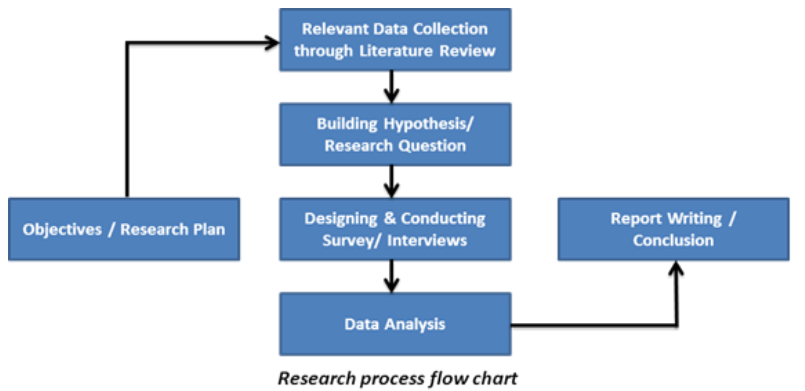

VI. Data Analysis \& Interpretation Of Variables

In this chapter, analysis and interpretation of the collected data has been performed. Statistical quantities of each variable have been analyzed through the frequency tables and summarized to uncover the important characteristics of gathered data.

\subsection{Innovation is important for progress \& survival}

\begin{tabular}{|ll|r|r|r|r|}
\hline & & Frequency & Percent & Valid Percent & Cumulative Percent \\
\hline Valid & Strongly Agree & 87 & 55.1 & 55.4 & 55.4 \\
& Agree & 40 & 25.3 & 25.5 & 80.9 \\
& Disagree & 22 & 13.9 & 14.0 & 94.9 \\
& Strongly & 8 & 5.1 & 5.1 & 100.0 \\
& Disagree & 157 & 100.0 & & \\
\hline
\end{tabular}

Table 6.1: Showing frequency of variable 01

Enquiring about whether in their views, the innovation was important for progress \& survival or not, the respondents came up with varied degrees of replies. A majority of about 55\% (87 out of 157) strongly held it in affirmative, whereas $25.3 \%$ did agree to the notion, albeit to a bit lesser degree. A total of about $19 \%$ did not agree with the innovation being a necessary pre-requisite for progress and survival, a subset of which, comprising of about 5\% had an opinion of disagreement, with strong conviction. A good proportion of those who strongly agreed held this opinion on their belief that without pursuing innovation in Information Technology, the chances of lagging behind in these times of cut throat competition are increased. Another subset of this subgroup opined that more than the technology itself, it is the pace-keeping with the contemporary competitors in the market which bears more importance, as, to them, the psychological perception of the client with regards to the organization, in views of the maintenance of standards is the point of primary focus than even the efficiency, in literal sense of the word.

Similarly those who disagreed held varied opinions behind their perceptions. Some thought it is just a waste of time, money and energy to constantly keep pursuing innovations in information technology without substantial good results, i.e. in their views it was like putting too much effort for too little return. While the other group thought that excessive innovation, and that too, very rapid in evolution, itself causes impediments and produce sluggish results. To them, the rate of advancements in information technology was too high in comparison to an organization's capacities to invest in this regard, most often than not which has been depicted in the Figure 6.1.

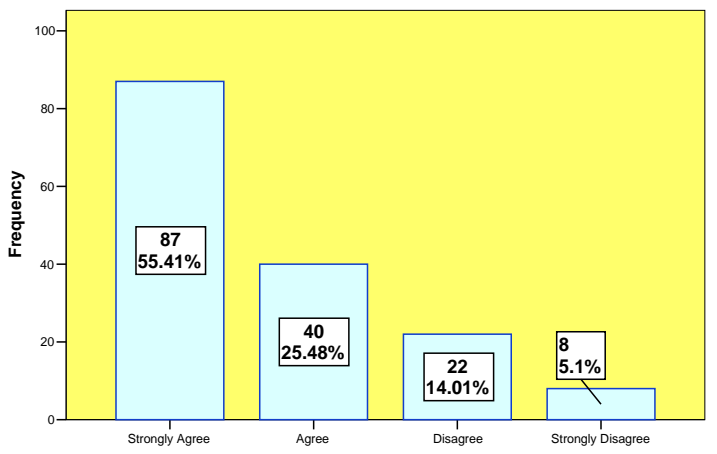

Fig. 6.1: Innovation is important for progress \& survival. 


\subsection{Outsourcing IT to gain innovation}

\begin{tabular}{|c|c|c|c|c|}
\hline & Frequency & Percent & Valid Percent & $\begin{array}{c}\text { Cumulative } \\
\text { Percent }\end{array}$ \\
\hline No response & 8 & 5.1 & 5.1 & 5.1 \\
\hline Yes & 109 & 69.0 & 69.4 & 74.5 \\
\hline No & 40 & 25.3 & 25.5 & 100.0 \\
\hline Total & 157 & 100.0 & & \\
\hline
\end{tabular}

Table 6.2: Showing frequency of the variable 02

When it was enquired by the participants that whether they outsource IT (Information Technology) to gain innovation or not, then majority of them i.e. 69.4\% (109 out of 157) came up with the positive response endorsing that outsourcing IT brings them innovation whereas $25.4 \%$ respondents did not agree that outsourcing IT could play role in facilitating innovation and gave their response in negative. However, $5 \%$ of the participants did not give any response in return.

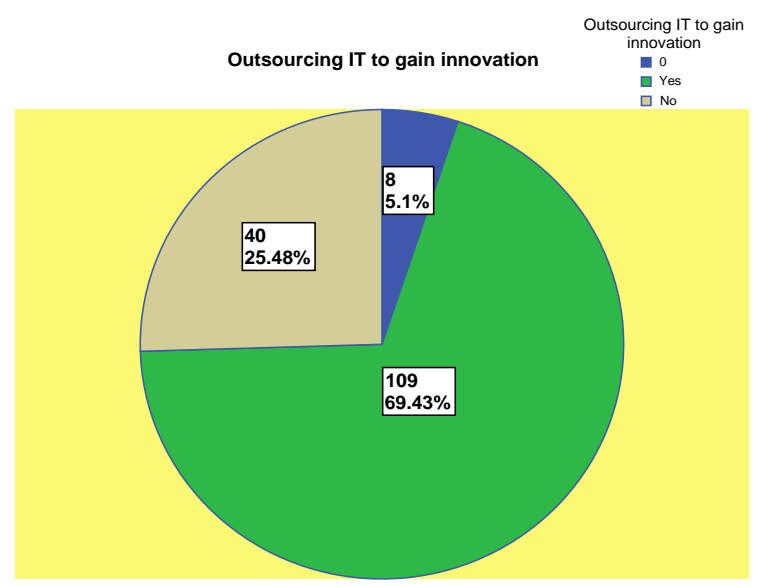

Fig. 6.2: Outsourcing IT to gain innovation

6.3 Priorities for investment

\begin{tabular}{|ll|r|r|r|r|}
\hline & & & & \multicolumn{2}{c|}{$\begin{array}{c}\text { Cumulative } \\
\text { Percent }\end{array}$} \\
\hline Val & Core services \&R\&D & Frequency & Percent & Valid Percent & 60.5 \\
id & HRD \& Risk Management & 35 & 60.1 & 60.5 & 85.4 \\
& Communication \&Marketing & 24 & 24.7 & 24.8 & 100.0 \\
& & 157 & 14.6 & 14.6 & \\
Total & & 100.0 & & \\
\hline
\end{tabular}

Table 6.3: Showing frequency of the variable 03

In order to find out whether the priorities of firms for investment meets the need to facilitate innovation or not, six major areas were selected and categorized in three categories which were then placed before the respondents. Majority of about 60\% (95 out of 157) firms came up in favour of investment towards Core Services and R\&D (Research \& Development) whereas $24.7 \%$ supported the investment in the area of HRD (Human Resource Development) and Risk Management. However, about $14.6 \%$ supported the investment towards Communication and Marketing. As per results, majority of the firms supported the investment towards their core services and R\&D which shows their focus towards constant production as well as improvement through research and development which according to most of them would provide them with scientific and reliable evidence towards forecasting and better decision making. 


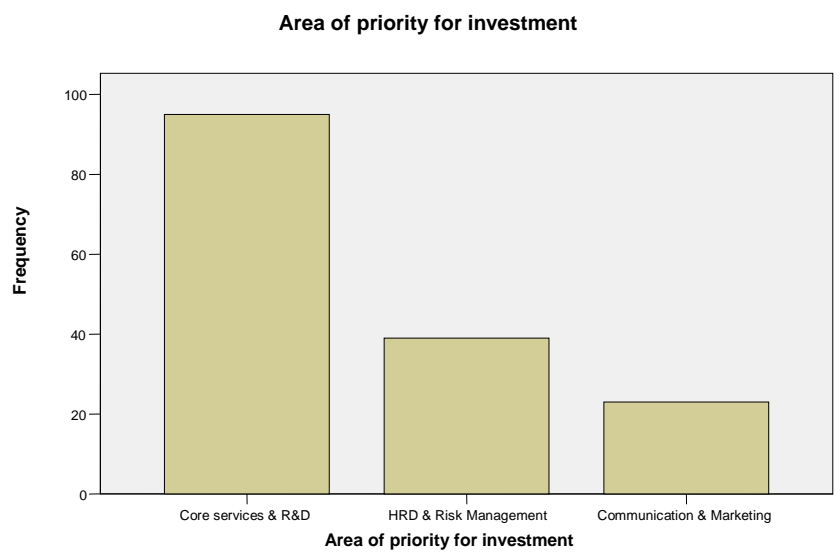

Fig. 6.3: Showing areas of priority for investment

\subsection{Investment in Research \& Development}

\begin{tabular}{|ll|r|r|r|r|}
\hline & & & & \multicolumn{2}{c|}{$\begin{array}{c}\text { Cumulative } \\
\text { Percent }\end{array}$} \\
\hline Valid & Nothing & 30 & 19.0 & 19.1 & 19.1 \\
& $5 \%$ & 16 & 10.1 & 10.2 & 29.3 \\
& $10 \%$ & 23 & 14.6 & 14.6 & 43.9 \\
& $15 \%$ & 36 & 22.8 & 22.9 & 66.9 \\
& $20 \%$ & 28 & 17.7 & 17.8 & 84.7 \\
& $25 \%$ & 15 & 9.5 & 9.6 & 94.3 \\
& More than 25\% & 9 & 5.7 & 5.7 & 100.0 \\
\hline
\end{tabular}

Table 6.4: Showing frequency of the variable 04

Research and Development is an area in which new ideas and findings are produced and considered as an important indicator of innovation. When respondents were enquired about their investment in R\&D, about $19 \%$ of them were those who invested nothing on R\&D whereas $22.8 \%$ were those who preferred to invest $15 \%$ in $R \& D$ which is the highest figure recorded in this survey. If firms with zero percent investment in R\&D (i.e. $19 \%$ ) are excluded, the data shows a normal frequency distribution of the remaining $80.4 \%$ of the firms, investing in the $\mathrm{R} \& \mathrm{D}$

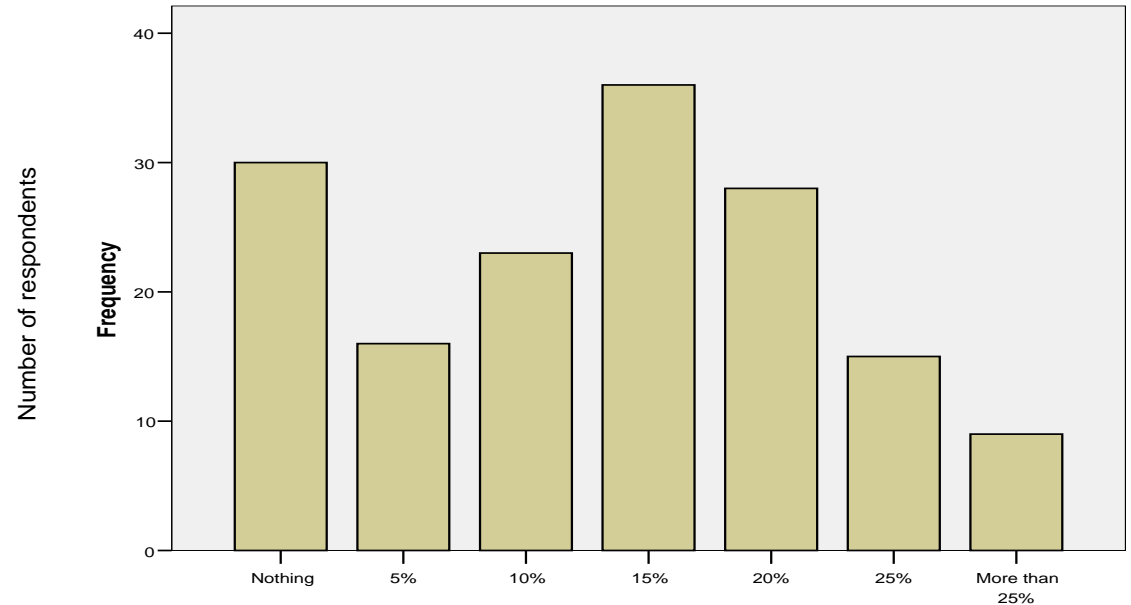

Fig. 6.4: Investment in Research and Development 


\subsection{Proportion of technical employees}

\begin{tabular}{|ll|r|r|r|r|}
\hline & \multicolumn{2}{|c|}{ Frequency } & Percent & Valid Percent & \multicolumn{2}{c|}{$\begin{array}{c}\text { Cumulative } \\
\text { Percent }\end{array}$} \\
\hline Valid & $10 \%$ & 15 & 9.5 & 9.6 & 9.6 \\
& $15 \%$ & 38 & 24.1 & 24.2 & 33.8 \\
& $20 \%$ & 5 & 5.1 & 5.1 & 38.9 \\
& $25 \%$ & 8 & 5.1 & 5.1 & 43.9 \\
& More than 25\% & 88 & 55.7 & 56.1 & 100.0 \\
Total & & 157 & 100.0 & & \\
\hline
\end{tabular}

Table 6.5: Showing frequency of the variable 05

Probing on the technical staff/employees working in the firms, the majority of about $55.7 \%$ (88 out of 157) firms showed to have more than $25 \%$ of the technical staff, whereas, about $24 \%$ (38 out of 157) of firms showed an inclusion of about $15 \%$ of the technical staff. However, those firms having $10 \%, 20 \%$ and $25 \%$ of technical staff were few in numbers.

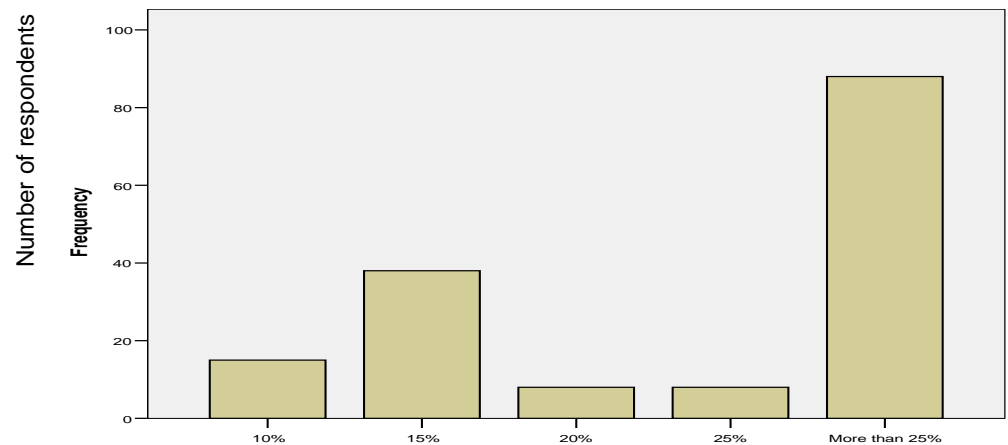

Fig. 6.5: Proportion of technical employees

\subsection{Seminars, Conferences, Workshops, etc held}

\begin{tabular}{|ll|r|r|r|r|}
\hline & & & & \multicolumn{2}{c|}{$\begin{array}{c}\text { Cumulative } \\
\text { Percent }\end{array}$} \\
\hline Valid & Often & Frequency & Percent & Valid Percent & 19.7 \\
& Rarely & 31 & 19.6 & 19.7 & 70.7 \\
& No & 80 & 50.6 & 51.0 & 100.0 \\
Total & & 29.1 & 29.3 & \\
\hline
\end{tabular}

Table 6.6: Showing frequency of the variable 09

Conducting seminars, conferences, workshops and other training courses are important for gaining and sharing new knowledge and technology. During the survey when question was asked regarding the participation of the firms in such events then majority of about 50.6\% (80 out of 157) firms found rarely participates or conducts such events whereas, $29 \%$ responded negatively and only $19.6 \%$ firms found participatory in such activities which is surprisingly low if compare in light of their investment priorities towards Research and Development $(R \& D)$ in order to gain sustainable progress through innovative solutions.

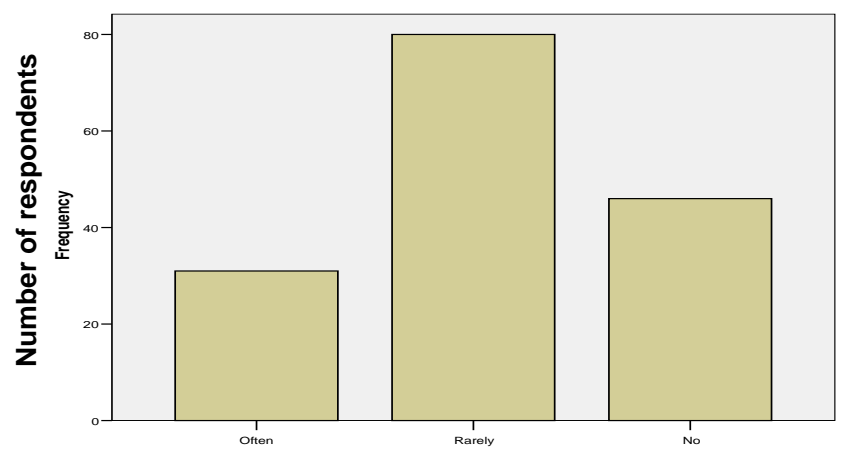

Fig. 6.6: Seminars, Conferences, Workshops, etc held 
6.7 Number of firms having patents

\begin{tabular}{|ll|r|r|r|r|}
\hline & & & & \multicolumn{2}{c|}{$\begin{array}{c}\text { Cumulative } \\
\text { Percent }\end{array}$} \\
\hline Valid & No Patents & 109 & 69.0 & \multicolumn{1}{c|}{ Valid Percent } & 73.2 \\
& 1 & 16 & 10.1 & 10.7 & 73.2 \\
& 4 & 8 & 5.1 & 5.4 & 83.9 \\
& 5 & 16 & 10.1 & 10.7 & 100.0 \\
Total & 157 & 100.0 & & \\
\hline
\end{tabular}

Table 6.7: Showing frequency of the variable 10

Patent is considered as the most important indicator for measuring the output of any research or technology related organization. In this regard when firms were enquired about their number of patents then majority of about 69\% (109 out of 157) found having no patent on their credit. Whereas, $10 \%$ firms were those who had single patent and equally percentage of firms were found having 05 patents on their credit. About $5.1 \%$ firms were those who had 04 patents which is the lowest figure in this survey. However, some of the firm's representatives disagree to disclose the number of patents, declaring it as 'official secret' and some of them were unaware or had blur concept of the term patent.

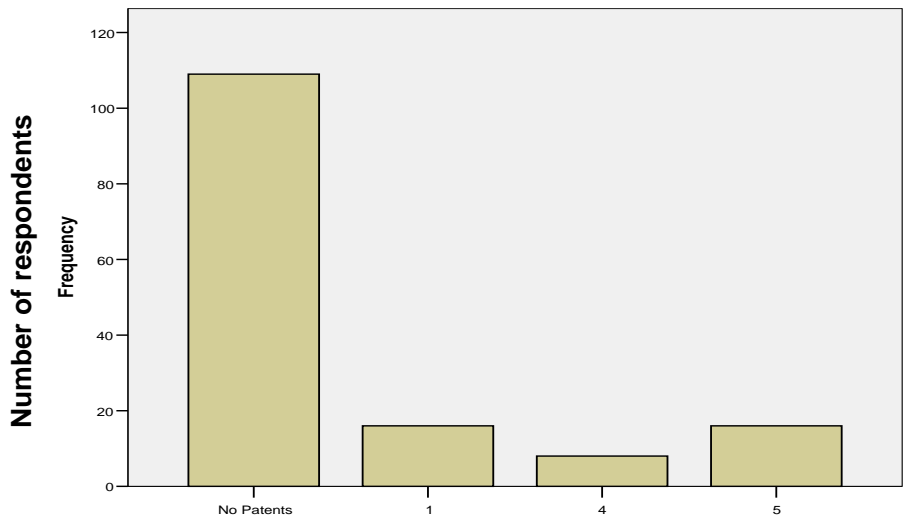

Fig. 6.7: Number of firms having patents

VII. Correlations And Associations

In order to determine, the existence of any possible relations and associations among different variables, correlation analysis has been performed by cross tabulating the variables and put under the Pearson Chi-square test for independence. In-depth analysis of variables will provide statistical evidences with strong reasons about the possible impact of outsourcing IT over performance of business firm. This analysis will help in progress towards achieving the objective of this study i.e. to identify the most influential factors that may have positive impact over performance and innovative capabilities of ITO firm.

\subsection{Correlation between Area of priority for investment and Number of firms having patents.}

In this analysis, both the variables 'priority_invest' (Area of priority for investment) and 'firms_patents' (Number of firms having patents) have been put under Chi-square test for independence in order to determine whether they are related or not.

Area of priority for investment * Number of registered patents Crosstabulation

\begin{tabular}{|c|c|c|c|c|c|c|}
\hline & \multicolumn{4}{|c|}{ Number of registered patents } & \multirow[b]{2}{*}{ Total } \\
\hline & & No Patents & 1 & 4 & 5 & \\
\hline \multirow{3}{*}{$\begin{array}{l}\text { Area of } \\
\text { priority for } \\
\text { investment }\end{array}$} & Core services \& R\&D & 71 & 16 & 8 & 0 & 95 \\
\hline & HRD \& Risk Management & 15 & 0 & 0 & 16 & 31 \\
\hline & $\begin{array}{l}\text { Communication \& } \\
\text { Marketting }\end{array}$ & 23 & 0 & 0 & 0 & 23 \\
\hline Total & & 109 & 16 & 8 & 16 & 149 \\
\hline
\end{tabular}

Table 1: Showing Cross tabulation No. 01 


\section{Test Result}

The concept of 'innovative capabilities' of any business firm is to produce new products, services or new markets (Talaja, 2012), so as the output of R\&D activities of such business firms are different from others and are not measured in terms of scientific or laboratory based experiments. In fact, the output of R\&D activates is measured in terms of numbers of patents the company has produced. In this regard, the test result is showing that the large number of firms who are investing in $R \& D$ for innovative outcome has less number of patents registered on their credit and the investment in R\&D activities is not properly been utilized, managed or going in vain. For instance, 71 firms that have shown strong agreement towards investing in core-services and R\&D, have few or no patents registered on their credit.

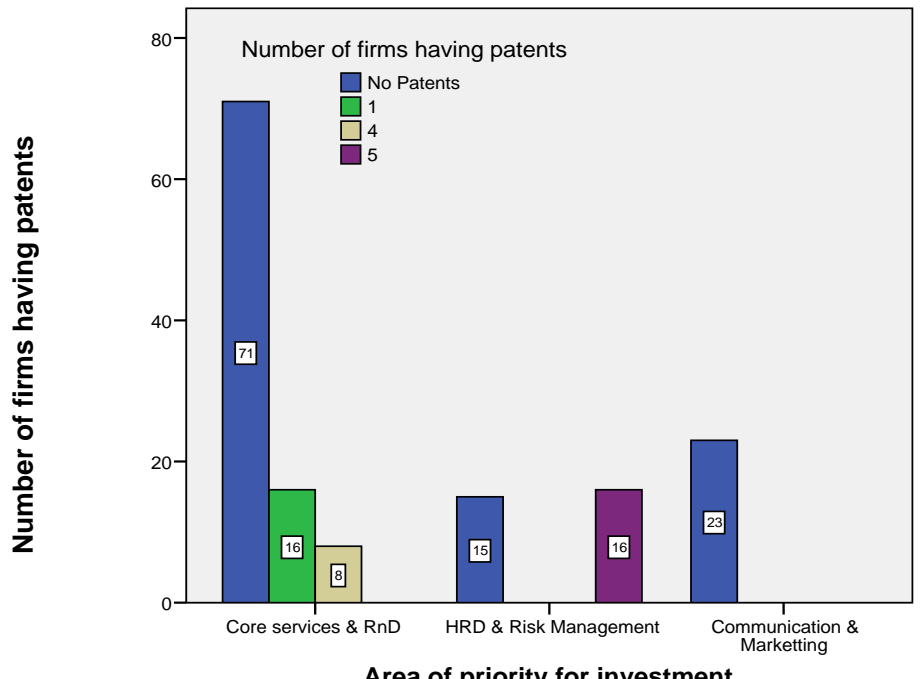

Fig. 7.1: Showing correlation between Area of priority for investment with Nos. of firms having patents

The Pearson chi-square value is ' 79.443 ' shown in Table 1, which is a very high with an associated significance level of " 0.000 " presented in the column labeled 'Asymp. Sig. ( 2 sided). To be significant, the 'Sig.' value needs to be ' 0.05 ' or smaller. In this case, the value of ' 0.000 ' is much smaller than the alpha value of 0.05 , so it concludes that there is a significant difference in both the variables and the variation in result is not be chance.

Chi-Square Tests

\begin{tabular}{|c|c|c|c|}
\hline & Value & df & $\begin{array}{l}\text { Asy mp. Sig. } \\
\text { (2-sided) }\end{array}$ \\
\hline Pearson Chi-Square & $79.443^{a}$ & 6 & .000 \\
\hline Likelihood Ratio & 76.860 & 6 & .000 \\
\hline $\begin{array}{l}\text { Linear-by-Linear } \\
\text { Association }\end{array}$ & .786 & 1 & .375 \\
\hline $\mathrm{N}$ of Valid Cases & 149 & & \\
\hline
\end{tabular}

Table 2: significance level of 'priority_invest' and 'firms_patents'

7.2 Correlation between Proportion of technical employees and Seminars, Conferences, Workshops etc held.

\begin{tabular}{|c|c|c|c|c|c|}
\hline & & \multicolumn{3}{|c|}{$\begin{array}{c}\text { Seminars, Conf erences, } \\
\text { Workshops, etc held }\end{array}$} & \multirow[b]{2}{*}{ Total } \\
\hline & & Often & Rarely & No & \\
\hline \multirow{5}{*}{$\begin{array}{l}\text { Proportion } \\
\text { of technical } \\
\text { employees }\end{array}$} & $10 \%$ & 0 & 8 & 7 & 15 \\
\hline & $15 \%$ & 7 & 16 & 15 & 38 \\
\hline & $20 \%$ & 0 & 0 & 8 & 8 \\
\hline & $25 \%$ & 8 & 0 & 0 & 8 \\
\hline & More than $25 \%$ & 16 & 56 & 16 & 88 \\
\hline Total & & 31 & 80 & 46 & 157 \\
\hline
\end{tabular}

Table 7.1: Showing Cross tabulation No. 02 


\section{Test Result}

A similar sort of sense can be gain from the cross tabulation between 'tech_emp' (number of Technical employees) and 'seminar_etc' (Seminars, Conferences, Workshops etc held). It is found that the firms having large number of technical employees are more reluctant to conduct skill building events like seminars, conferences, training workshops etc. which reduces the chances of skills transmission among various employees and the same has been emphasized in Oslo Manual (2005) that "Human skills can be developed (through internal training) or purchased (by hiring); tacit and informal learning - "learning by doing" - may also be involved" (p.36), which is evidently be seen in the above table.

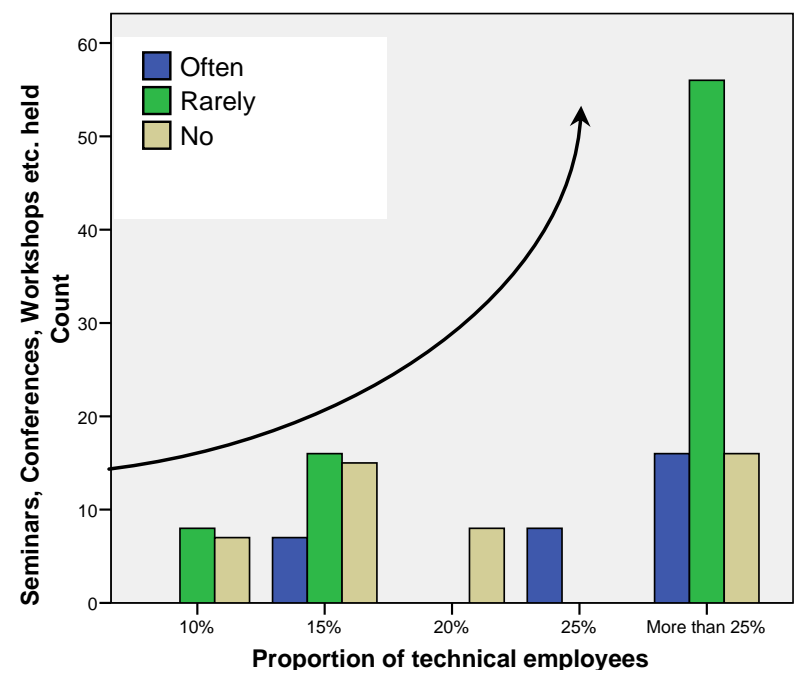

Fig.7.2. Showing correlation between technical employees with Seminars, Conferences, Workshops etc held

In this case the Pearson Chi-Square's corrected value in the below table is 64.902 associated with the significance level of ' 0.000 ' in the column labeled 'Asymp. Sig. ( 2 sided) which is showing significant difference in both the variables.

Chi-Square Tests

\begin{tabular}{|l|r|r|r|}
\hline & \multicolumn{1}{|c|}{ Value } & \multicolumn{1}{c|}{ df } & \multicolumn{1}{|c|}{$\begin{array}{c}\text { Asy mp. Sig. } \\
\text { (2-sided) }\end{array}$} \\
\hline Pearson Chi-Square & $64.902^{\mathrm{a}}$ & 8 & .000 \\
Likelihood Ratio & 61.691 & 8 & .000 \\
Linear-by-Linear & 6.547 & 1 & .011 \\
Association & 157 & & \\
N of Valid Cases & & \\
\hline
\end{tabular}

Table 7.2: Significance level of 'tech_emp' and 'seminar_etc'

\subsection{Correlation between (Firms) Outsourcing IT to gain innovation and Investment in R\&D}

Outsourcing IT to gain innovation * Investment in Research \& Development Crosstabulation

\begin{tabular}{|c|c|c|c|c|c|c|c|c|c|}
\hline & & \multicolumn{7}{|c|}{ Investment in Research \& Dev elopment } & \multirow[b]{2}{*}{ Total } \\
\hline & & Nothing & $5 \%$ & $10 \%$ & $15 \%$ & $20 \%$ & $25 \%$ & $\begin{array}{c}\text { More than } \\
25 \%\end{array}$ & \\
\hline \multirow{3}{*}{$\begin{array}{l}\text { Outsourcing IT to } \\
\text { gain innov ation }\end{array}$} & 0 & 0 & 0 & 0 & 1 & 0 & 7 & 0 & 8 \\
\hline & Yes & 22 & 16 & 18 & 25 & 15 & 8 & 5 & 109 \\
\hline & No & 8 & 0 & 5 & 10 & 13 & 0 & 4 & 40 \\
\hline Total & & 30 & 16 & 23 & 36 & 28 & 15 & 9 & 157 \\
\hline
\end{tabular}

Table 1: Showing Cross tabulation No. 03 


\section{Test Result}

In the cross tabulation of variables 'gain inn' (Outsourcing IT to gain innovation) with 'invest_R\&D' (Investment in R\&D), it is found that majority of the firms who had agreed that they outsource IT to gain innovation were investing more in $\mathrm{R} \& \mathrm{D}$ activities as compared to those who negate such outsourcing activity excluding those who invest nothing in R\&D which are 22 in nos. as depicted in Fig.7.1.

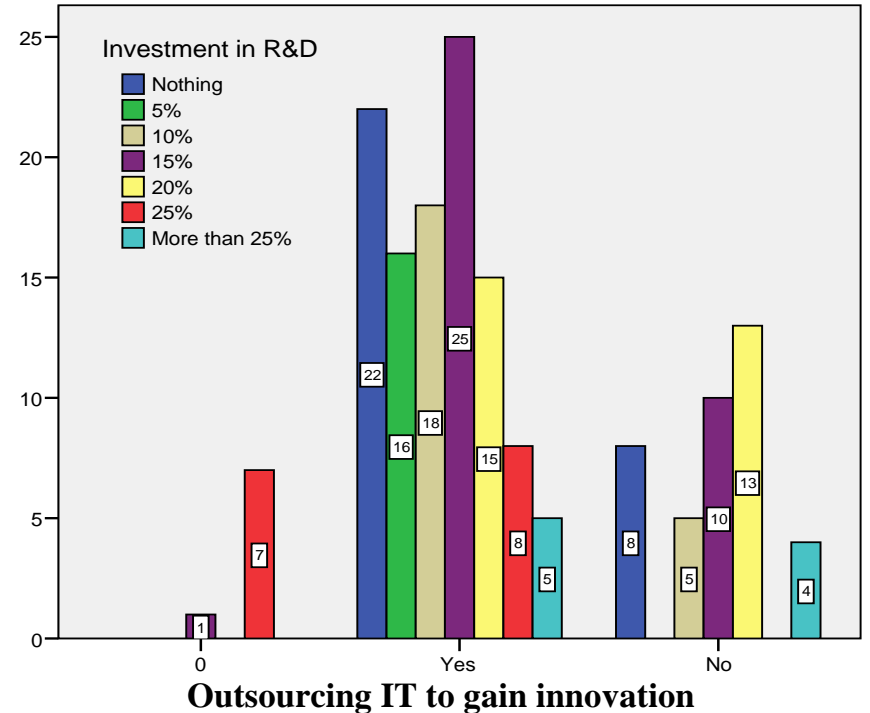

Fig.7.1 Correlation of Investment in R\&D with (Firms) Outsourcing IT to gain innovation

The significance level found in the Pearson Chi-square test in this correlation is ' 0.000 ' which is much smaller than the value ' 0.05 ' presented in the column labeled 'Asymp. Sig. (2-sided)'. In this case, the results are found significant.

Chi-Square Tests

\begin{tabular}{|l|r|r|r|}
\hline & Value & df & \multicolumn{1}{c|}{$\begin{array}{c}\text { Asy mp. Sig. } \\
\text { (2-sided) }\end{array}$} \\
\hline Pearson Chi-Square & $75.165^{\mathrm{a}}$ & 12 & .000 \\
Likelihood Ratio & 54.902 & 12 & .000 \\
Linear-by-Linear & .003 & 1 & .959 \\
Association & 157 & & \\
N of Valid Cases & & & \\
\hline
\end{tabular}

Table 7.2 Showing Significance level of 'invest_R\&D' and 'gain_inn'

\subsection{Correlation between Number of firms having patents and (Firms) Outsourcing IT to gain innovation}

Outsourcing IT to gain innovation * Number of registered patents Crosstabulation

\begin{tabular}{|ll|r|r|r|r|r|r|}
\hline \multicolumn{1}{|c|}{ Count } & \multicolumn{5}{|c|}{ Number of registered patents } & \multirow{2}{*}{ Total } \\
\cline { 2 - 8 } & & No Patents & 1 & 4 & 5 & 8 \\
\hline Outsourcing IT to & 0 & 8 & 0 & 0 & 0 & 109 \\
gain innov ation & Yes & 85 & 0 & 8 & 16 & 32 \\
& No & 16 & 16 & 0 & 0 & 149 \\
Total & & 109 & 16 & 8 & 16 & 0 \\
\hline
\end{tabular}

\section{Test Result}

Table 7.1 Showing Cross tabulation No. 04

In the correlation of variables 'num_patents' (Number of firms having patents) with 'gain_inn' (Outsourcing IT to gain innovation), it is found that the majority of about 24 firms who had agreed that they outsource IT to gain innovation had large number of registered patents on their credit. For instance, 08 firms were having 04 patents and 16 firms were having 05 patents each as compared to those who negate the above 
notion were having 01 patent each on their credit as shown in Fig. 7.1.

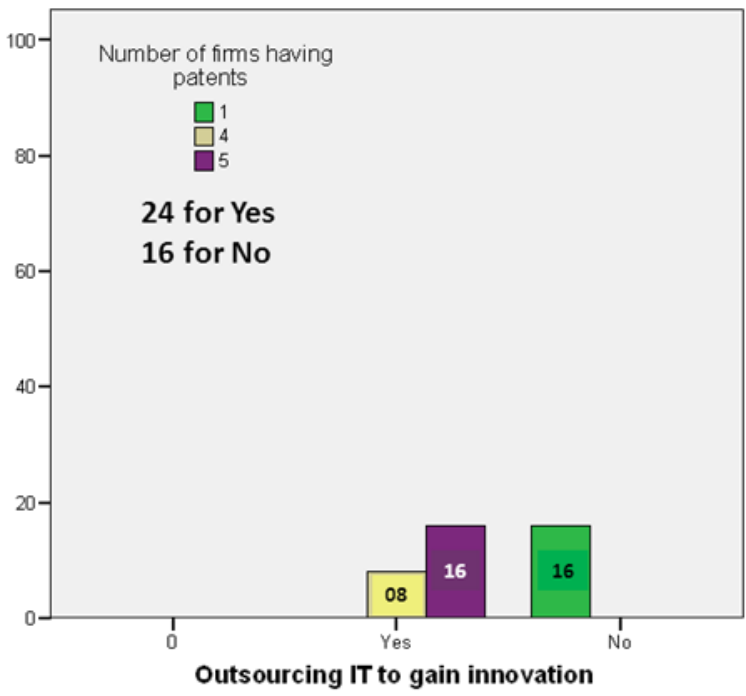

Fig.7.1 Showing correlation between Number of firms having patents with (Firms) Outsourcing IT to gain innovation

In light of the above result, it has also found that firms who outsource IT in order to gain innovation, invests more in R\&D and have more number of patents on their credit as compare to others. Even the results found significant, as the alpha value found in this case ' 0.000 ' less than ' 0.05 '.

Chi-Square Tests

\begin{tabular}{|c|c|c|c|}
\hline & Value & df & $\begin{array}{l}\text { Asy mp. Sig. } \\
\text { (2-sided) }\end{array}$ \\
\hline Pearson Chi-Square & $70.788^{a}$ & 6 & .000 \\
\hline Likelihood Ratio & 67.915 & 6 & .000 \\
\hline $\begin{array}{l}\text { Linear-by-Linear } \\
\text { Association }\end{array}$ & .201 & 1 & .654 \\
\hline $\mathrm{N}$ of Valid Cases & 149 & & \\
\hline
\end{tabular}

Table 7.2 Showing Significance level of 'num_patents' and 'gain_inn'

\section{Conclusion}

In light of above analysis, it is found that majority of firms who are outsourcing IT services in order to gain innovation are investing more in $R \& D$ and have more patents registered on their credit unlike those firms who do not outsource IT services. Results of the analysis found significant which indicates that the variation in the results is not by chance and there must be some factors are playing their part causing such variations in the results shows that outsourcing IT services does contribute towards enhancing innovation in ITO firm/company.

\section{Limitations And Future Research}

Selecting IT outsourcing firms from Karachi is the primary limitation of this case study, due to easy access of data and a large share of active IT firms working in the city. The outcome of this study would be different if it is conducted in any other city or region.

Only influential factors were the main focus of this study however, outsourcing as a business model innovation would also be an interesting line of reasoning for future studies and for those who are interested in determining the role of innovation in outsourcing business. 


\section{References}

[1]. Ahmed. M., Raza. K. and Shahid. R (2012), Causes of increasing demand of Employees Outsourcing and its Impact on Pakistan Business for International Journal of Learning \& Development, ISSN 2164-4063, 2012.

[2]. BSA, Business Software Alliance (2007), Global Software Piracy Study [Online] Available at: http://www.bsa.org (Accessed on: 01 May 2010).

[3]. Golafshani, N. (2003), Understanding Reliability and Validity in Qualitative Research, The Qualitative Report. Vol. 8, Number 4 December 2003 597-607. [Online] Available at: http://www.nova.edu/ssss/QR/QR8-4/golafshani.pdf

[4]. Hoecht. A. and Trott. P. (2006), Innovation Risks of Strategic Outsourcing Technovation vol.26, (2006) 672-681. [Online] Available at: http://goo.gl/yzqFrb.

[5]. Li. Xiaolin, (2011), Study on Technological Innovation Outsourcing in Scientific and Technological Small and Medium-sized Enterprises Based on Motives, Asian Social Sciences: Vol. 7, No. 8.

[6] Mahar, A., Tunio, M. N., Soomro, W. A. (2013) Determining the Different E-Services Required By the Pakistani Citizens. IOSR Journal of Computer Engineering (IOSR-JCE) e-ISSN: 2278-0661, p- ISSN: 2278-8727 Volume 13, Issue 3 (Jul. - Aug. 2013), PP 01-04 www.iosrjournals.org

[7]. Marion. T. and Friar. J. (2012), Managing Global Outsourcing to Enhance Lean Innovation: Outsourcing techniques used by smaller firms can help larger firms keep R\&D lean while maintaining innovation efficiency, Feature Article: Research-Technology Management, Volume 55, Number 5, p-46.

[8]. MoIP, Ministry of Industries \& Production (2004), Prospects of IT industry in Pakistan, Experts Advisory Cell [Online] Available at: http://www.moip.gov.pk.

[9]. Oslo Manual, (2005), Guidelines for collecting and interpreting innovation data, OECD and Eurostat, 3rd edition. [Online] Available at: http://goo.gl/nGAU6

[10]. Oshri. I, Kotlarsky. J. and Gerbasi. A. (2011), Can Client Firms Achieve Radical Innovation in IT Outsourcing? ICIS: International Conference on Information Systems, Shanghai, 2011 proceedings. Paper 4. [Online] Available at: http://goo.gl/217RpO.

[11]. PASHA, Pakistan Software Houses Association (2007) Annual Review of Pakistan's Software/BPO Industry. [Online] Available at: http://pasha.org.pk/wp-content/uploads/2011/01/P@SHA-IT-Industry-Report-2007-8.pdf

[12]. PSEB, Pakistan Software Export Board (2008) Pakistan IT Industry Yearbook 2007-08. [Online] Pakistan: PSEB. p.9. Available at: http://goo.gl/XLX5Uz

[13]. Stanko, M. A. and Calantone, R. J. (2011) Controversy in innovation outsourcing research: Review, Synthesis and Future directions, R\&D Management, Blackwell Publishing Ltd, vol.41 (1), pp. 8-20.

[14]. Talaja, A. (2012), Innovative capabilities, firm performance and foreign ownership: Empirical analysis of large and medium-sized companies form all industries, Technology Transfer and Innovation International Conference, Proceedings, Vol. 1, Issue 1, 2012, pp.22-31.

[15] Tunio, M. N., Mahar, A., Soomro, W. A. , Abro, Q. M. M. (2013) Recognizing the available and proposed e-services in Pakistan . International Journal of Innovative Social Sciences \& Humanities Research 1(2):37-42.

[16]. Wang, C., Ahmed, P. (2007), Dynamic capabilities: A review and research agenda, International Journal of Management Reviews, Vol.9 (1), pp.31-51

[17]. Whitman, M. (1996), IT divergence in re-engineering support: Performance expectations Vs Perceptions. Information \& Management, 30(5), 239-250. 